\title{
Tectonic effects on the drainage disposition in mountain slopes and orogen forelands. A case study: the Central Andes of Argentina
}

\author{
Graciela Mabel Suvires ${ }^{1,2}$, Ricardo Mon $^{3}$ \& Adolfo Antonio Gutiérrez ${ }^{3}$
}

\begin{abstract}
The evolution of the drainage pattern of the eastern Andes has proven to be a valuable indicator of tectonic phenomena that occurred between the Early Miocene and the Late Quaternary. In this work a 1000-kmlong segment of the central Andes between $27^{\circ}$ and $34^{\circ} \mathrm{S}$ has been studied. This segment has been identified as an area of intense seismic and quaternary tectonic activity. The stage for these neotectonic manifestations is found to the east of the magmatic arc of the Principal Cordillera and the Frontal Cordillera in the western territories of La Rioja, San Juan, and Mendoza provinces (Argentina). The most significant characteristics of the topography of this region are the high mountain ranges that make up the Frontal and Principal Cordilleras, which reach altitudes that exceed 6,000 m. During the past $20 \mathrm{Ma}$, the deformation advanced from west to east and the mountain ranges began to rise. These mountains consist of fold and fault blocks that obstructed and diverted the rivers that flowed eastward. Because of this phenomenon a marked concentration of the drainage was produced in a decreasing number of rivers. This process culminated in the total concentration of the surface drainage in a single large trunk collector, the Colorado River, which drains into the Atlantic Ocean. Currently the deformation is still active in the easternmost strip of the Bermejo - Desaguadero valley characterized by high seismicity and movements as tested by geodetic measurements. The ages of the morphotectonic controls decrease from north to south and from west to east.
\end{abstract}

Keywords: Evolution of drainage system, Quaternary tectonic activity, San Juan-Colorado fluvial System.

\begin{abstract}
Resumo Controle tectônico sobre a drenagem desenvolvida na vertente oriental dos Andes centrais de Argentina. A evolução do padrão de drenagem dos Andes orientais tem provado ser um indicador valioso dos fenômenos tectônicos que ocorreram entre o início do Mioceno e Quaternário Tardio. Um segmento de $1.000 \mathrm{~km}$ de extensão da Cordilheira dos Andes central, entre $27^{\circ}$ e $34^{\circ} \mathrm{S}$ é considerado. Este segmento tem sido identificado como uma área de atividade sísmica e tectônica intensa no Quaternário. O palco para essas manifestações neotectônicas é encontrado a leste do arco magmático da Cordilheira Principal e Cordilheira Frontal nos territórios ocidentais das províncias de La Rioja, San Juan e Mendoza (Argentina). As características mais significativas da topografia desta região são as cadeias de montanhas elevadas que formam a Cordilheira Frontal e Principal, que alcançam altitudes que excedem 6.000 m. Nos últimos $20 \mathrm{Ma}$, a deformação avançadas do oeste ao leste e as serras começaram a subir. Estas montanhas consistem em pliegues e blocos da falha que obstruído e desviado os rios que fluíam para o oriente. Devido a esse fenômeno uma acentuada concentração da drenagem foi produzida em uma diminuição do número de rios. Este processo culminou com a concentração total da drenagem superficial em um coletor tronco único e grande, o rio Colorado, que desagua no Oceano Atlântico. Atualmente, a deformação é ainda ativa na faixa oriental do vale Bermejo-Desaguadero caracterizada por sismicidade alta e movimento como testado por meio de medições geodésicas. As idades dos controles morfotectônicos decréscimo do norte ao sul e de oeste a leste.
\end{abstract}

Palavras-chave: evolução do sistema de drenagem, atividade tectônica quaternária, San Juan-Colorado Sistema River.

INTRODUCTION Quaternary tectonism on the western edge of South America is reflected in the evolution of the drainage pattern of the eastern flank of the Andes and the adjacent foreland basin. This study focuses on the tectonic drivers of the spatial evolution of the drainage system of the central Andes between $27^{\circ} \mathrm{S}$ and $34^{\circ} \mathrm{S}$. As frequently occurs in the forelands of young, tectonically active orogens, the rivers that run along the mountain flank are diverted and concentrated by obstacles of tectonic origin into a smaller number of rivers (Gupta 1997, Mon 2005). In the central Andes, this process has special relevance. The geometry of the subduction of the Nazca plate below the South American plate controls the

1 - CONICET - National Council of Scientific and Technology Research, Buenos Aires, Argentina. E-mail: graciela_suvires@yahoo.com.ar 2 - Environmental Geology, Institute of Geology, National University of San Juan, San Juan, Argentina.

3 - College of Natural Sciences and the Miguel Lillo Institute, National University of Tucumán, Tucumán, Argentina. E-mail: ricardomon@arnet.com.ar, gutierrez.aa@hotmail.com 
Quaternary deformations and the topography of the Andean Ranges, which extends for more than 8,000 $\mathrm{km}$ along the edge of South America between $4^{\circ} \mathrm{S}$ and 46³0’S (Costa et al. 2006).

The area considered is found on a subduction section of a very low angle between $5^{\circ}$ and $10^{\circ}$, located between $27^{\circ} \mathrm{S}$ and $33^{\circ} \mathrm{S}$. On the other hand it has an angle close to $30^{\circ}$ between $18^{\circ} \mathrm{S}$ and $27^{\circ} \mathrm{S}$ similar to that of the southern region at $33^{\circ} \mathrm{S}$ (Ramos 1996, Ramos et al. 2002, Costa et al. 2006, Lavenu 2006, Alvarado et al. 2007).

Neotectonic activity in the eastern Andean flank is found to the east of the magmatic arc of the Principal and Frontal Cordilleras, where a segment of around $1,000 \mathrm{~km}$ has been studied in the western territories of the provinces of La Rioja, San Juan, and Mendoza (Argentina).

Spatial analysis of the drainage system facilitates the establishment of relationships between drainage pattern morphology and the presence of tectonic obstacles.

REGIONAL GEOLOGICAL FRAMEWORK The study region forms part of the geological provinces of the Principal Cordillera, the Frontal Cordillera, and the Precordillera; it is bounded to the north by La Puna and to the east by the Sierras Pampeanas. La Puna is composed of mountains and broad intermediate valleys with an average altitude greater than 3,500 m, endorrheic drainage, and highly developed Cenozoic volcanism. The endorrheic drainage is a direct consequence of the ongoing tectonic uplift that occurred during the Quaternary (Turner 1979, Mon 2005). To the south of La Puna $\left(28^{\circ} \mathrm{S}\right)$ the ranges of the Frontal Cordillera and the Precordillera emerge. The Principal Cordillera is in en echelon position $\left(31^{\circ} \mathrm{S}\right)$ towards the west (Fig. 1). This Cordillera is distinguished by the presence of thick Jurassic and Cretaceous marine and continental sedimentary sequences, which unconformably lie on the Paleozoic basement of the Frontal Cordillera and are partially covered by Mesozoic and Tertiary volcanic layers (Yrigoyen 1979). It is bordered to the east by the Frontal Cordillera, which is devoid of Jurassic and Cretaceous sequences and is instead composed of Carboniferous and Permo-Triassic, volcanic, pyroclastic, sequences that unconformably cover a lower Paleozoic basement. The Precordillera is a folded and faulted belt formed preponderantly by lower Paleozoic marine sequences that, to the east of the Cordillera Frontal, runs from the southern edge of La Puna at $27^{\circ} \mathrm{S}$ (Furque \& Cuerda 1979) to just south of the Mendoza River $\left(33^{\circ} \mathrm{S}\right)$, where the Paleozoic deposits are covered by Tertiary continental beds. Large blocks of the crystalline basement of the Sierras Pampeanas thrust to the west by major faults mark the eastern edge of the drainage system of this Andean section.

REGIONAL SETTING The most significant traits of this region are the Frontal and Principal Cordilleras. These ranges reach altitudes that exceed $6,000 \mathrm{~m}$, including the Aconcagua at 6959 m.a.s.l. (32³9'S, $70^{\circ} 01^{\prime} \mathrm{W}$ ) in the Principal Cordillera and the Toro at 6168 m.a.s.l. (2908'38’, 6947'50”) in the Frontal Cordillera. North of the $31^{\circ} 15^{\prime}$ parallel, is the divide separating the drainage of the Pacific flank in the west from that of the Atlantic in the east. These high mountain ranges have a generally north-south orientation and are separated from the Precordillera by the Uspallata, Barreal, Calingasta, and, Iglesias valleys, a 350-kmlong tectonic depression (Fig. 1). The Bermejo valley separates the Precordillera from the Sierras Pampeanas. From north to south, the main river basins correspond to the Jáchal, San Juan, Mendoza, and Tunuyán rivers (Figs. 2 and 3). Disconnected from the river valleys, there are small endorrheic basins represented by bogs, mud flat and salt pans that occupy tectonic depressions such as Gualilán, El Júmeal and Las Salinas (Fig. 1).

CLIMATIC CONDITIONS The Andes an important barrier to moisture coming from the Pacific Ocean, such that, in the region low precipitation is recorded and arid conditions and sparse vegetation are predominant. In large sectors the annual precipitation varies between 50 $\mathrm{mm}$ and $100 \mathrm{~mm}$. Snowfall on the high peaks, toward the south constitutes the main water source and is the origin of the rivers in this region. However, information regarding this solid precipitation is admittedly quite poor. The rivers results from Andean snowmelt, and there is a direct relationship between the snowfall in the Andes and the flow of the rivers (Prieto \& Herrera 2002). The entire area experiences at least one day of snow per year, with some sections receiving more than 70 days of snow per year (Snaider 2002). Precipitation increases with altitude and from north to south. For example, annual precipitation exceeds $700 \mathrm{~mm}$ in the high mountains in the headwaters of the San Juan River (Minetti 1984, 1986).

DRAINAGE CONTROLS As frequently occurs in the forelands of young, tectonically active orogens, the rivers that run through the mountain front are diverted and concentrated by obstacles of tectonic origin into a smaller number of rivers (Gupta 1997, Mon 2005). The central Andes of Argentina provide a particularly notable example of this phenomenon (Figs. 1 and 2). This region experiences intense seismic and Quaternary tectonic activity. Folds and faults that affect Pleistocene environment have been described by Cortés 1993, Cortés 


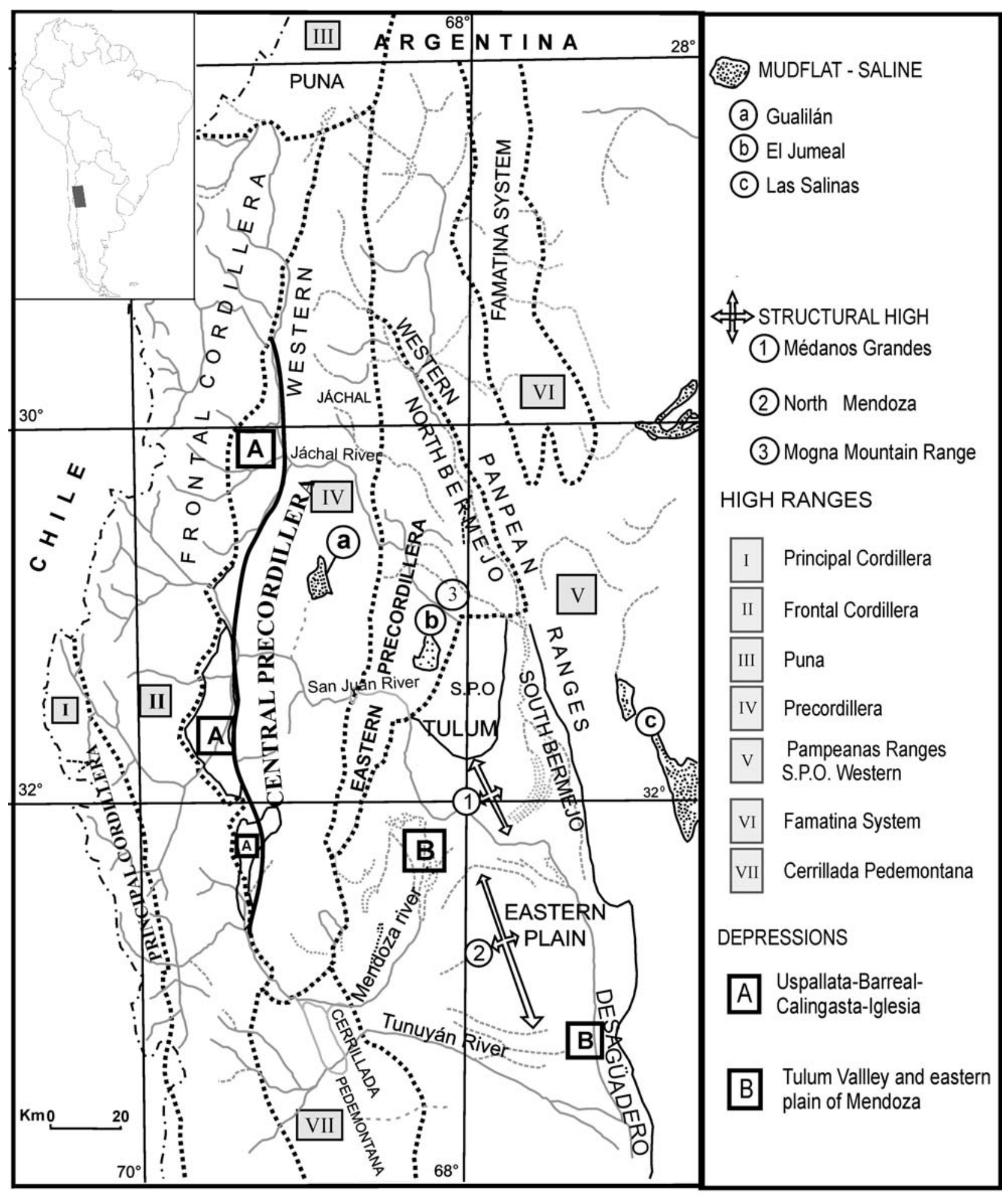

Figure 1 - Map of the central Andes between $27^{\circ} \mathrm{S}$ and $34^{\circ} \mathrm{S}$ : geological provinces and major structural and geographical features: mountain chains and tectonic depressions.

and Costa 1993, Cortés et al. 2006, Perucca et al. 2009, and Martinez et al. 2008, among others. In addition, diversions and changes in the rivers have been observed even in historic times. The diversions of the rivers constitute an indirect indicator of tectonic activity, which is related to different young structures. The surface water of this Andean segment, which is nearly 1,000-km-long in length between the parallels $27^{\circ} \mathrm{S}$ and $34^{\circ} \mathrm{S}$ is finally collected by the Colorado River, which flows into the Atlantic (Fig. 3). The origin of this concentration is related 


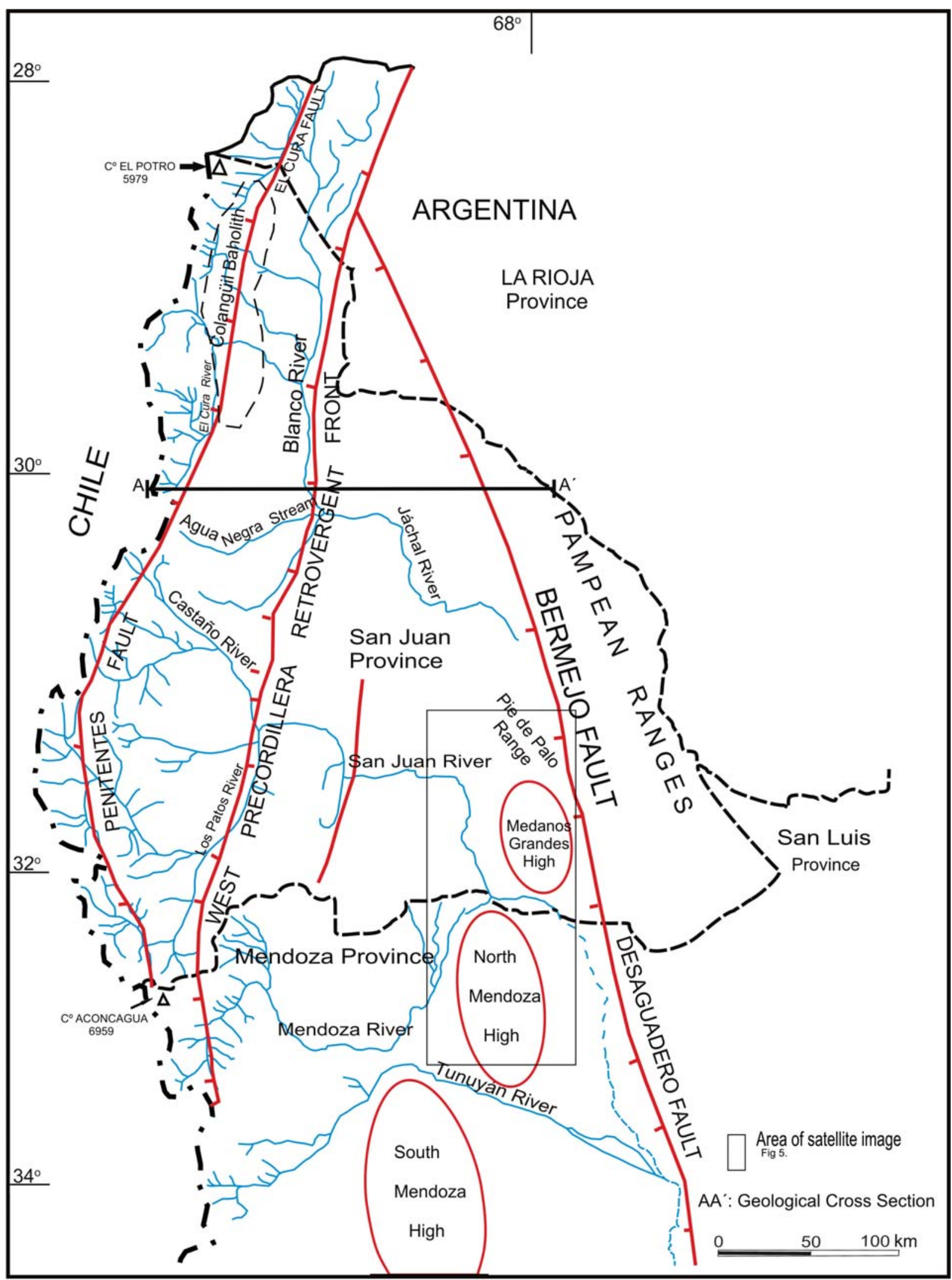

Figure 2 - Regional drainage of the central Andean region $\left(28-32^{\circ} S\right)$. The rivers are laterally diverted by the elevation of major thrust-blocks. This drainage reorganization is related to the evolution of a structurally controlled topography. From west to east the first drainage concentration is produced by the mountain fronts elevated by the Valle del Cura and Penitentes fauls. To the east the drainage is further concentrated by the fault blocks marking the west border of Precordillera (West Precordillera Front). 1 - North Mendoza High. 2 - South Mendoza High. The easternmost structure deviating the rivers is the Bermejo fault which marks the western border of Sierras Pampeanas. 


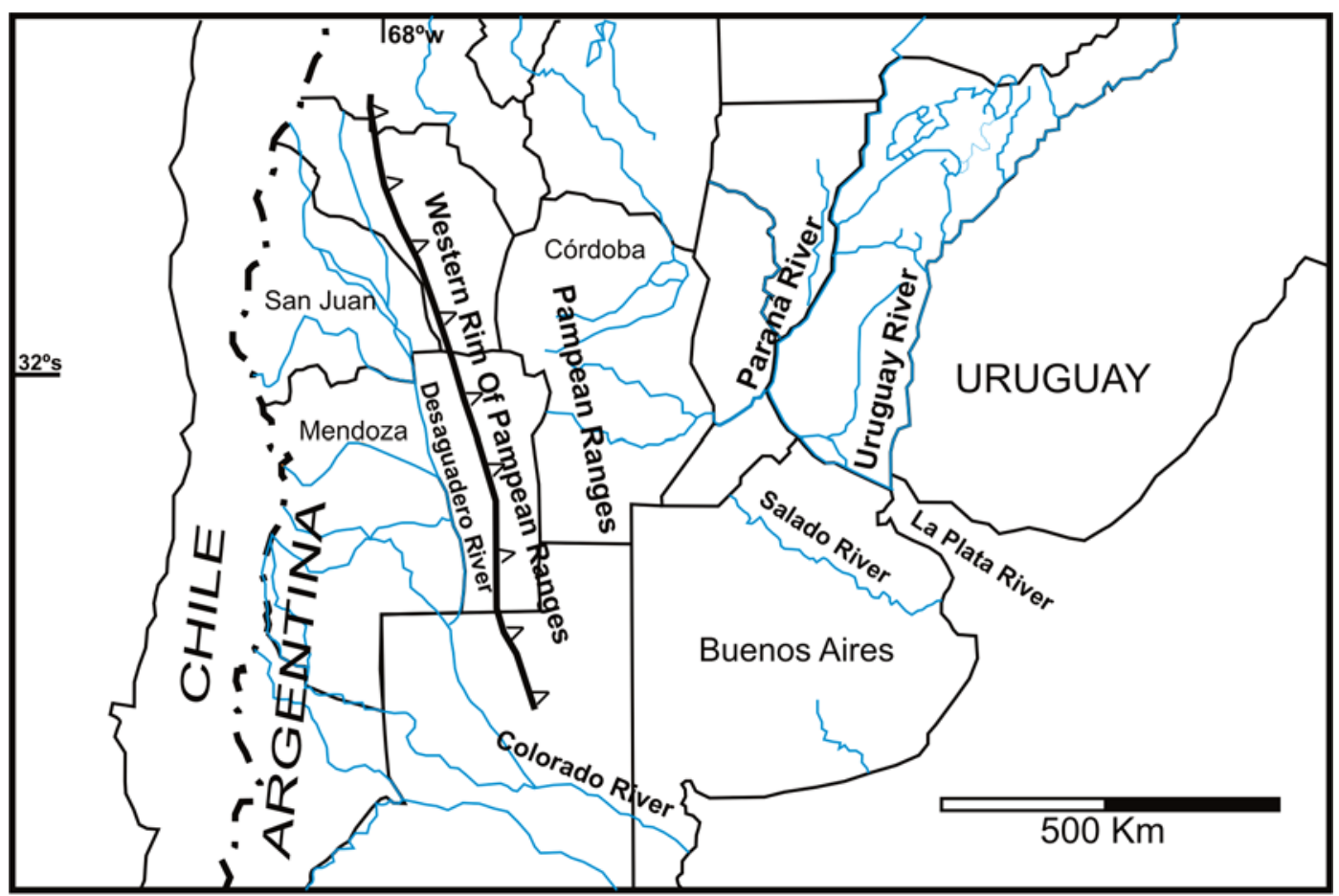

Figure 3 - Argentinean drainage systems. The major collectors Desaguadero and Colorado rivers are deviated by the fault blocks of the Sierras Pampeanas which represent a barrier impeding the eastward flow of the rivers and producing the final concentration of the drainage of the eastern flank of the Andes, This fluvial system debouches directly in the Atlantic Ocean through the Colorado River and is completely independent of the other major fluvial basin of Paraná and La Plata rivers.

to the progressive elevation of tectonic obstacles that have diverted, obstructed, and concentrated the rivers flowing through this part of the eastern Andean flank. Certain rivers must have run hundreds of kilometers from north to south before being able to open up to the east through weak zones of the mountain ranges that impeded their course. The obstacles that produce the diversions are of various kinds: cortical arching of long wavelength, steps related to exposed faults, flanks of regional scale folds, sheet edges raised by faults located on the opposite side of them or elevations of an undetermined origin that do not show visible relationships with faults. The diversion of the rivers is a consequence of uplift and of lateral growth of structures that compose the mountain ranges. It is assumed that rivers initially ran from the high peaks towards the east in approximately parallel channels. Prior to rivers being deviated, the drainage of the eastern flank of the Andes would have consisted of ten rivers approximately flowing to the east. With the onset of the Andean uplift 20 Ma ago, obstacles began to be lifted up, modifying the drainage pattern. Occasionally, the channels flow around the barriers, forming wide curves. In other cases, the river cuts the barriers along zones of lithological and structural weakness. When the rate of uplift of an obstacle is equal to or even greater than that of vertical erosion, deep gorges like the San Guillermo River are formed (Suvires 2008, Zambrano 2008) as shown in figure 3. Along the edges of the mountain ranges, channels are controlled by back-thrust fault lines; for example, the western edge of the Precordillera (Damanti 1993) controls the north-south course of the Blanco River and the Los Patos River (Fig. 2). In other cases, the diversion is produced behind structures elevated by a fault, such as the north-south section of the San Juan River in the Tulum Valley (Fig. 1). River diversion can be interpreted as the result of gradually rising mountainous barriers or the lateral growth of faulted belts or anticlines that propagate along blind faults like those observed in other sections of the Andes including northern Argentina (Mon 2005). Tectonic controls on the course orientations of large rivers have been recognized on all continents (Potter 1978). Many obstacles are clearly related to visible structures on the surface but, in other cases, the uplift does not show an evident relationship with outcropping tectonic features like eastern foreland peaks. The headwaters of most of 
the rivers in the region are located in the high peaks of the Principal and Frontal Cordilleras, which divide the watersheds flowing to the Pacific and the Atlantic. Runoff is increasingly concentrated to the east of this divide on the Atlantic flank. In the westernmost strip, the Macho Muerto River, the Blanco River headwaters, the De La Sal River, and the Taguas River are blocked by a tectonic step (Falla El Cura) and concentrated into two courses: the Blanco River and El Cura River (Fig. 2). Near the drainage divide to the south, the Falla Penitentes diverts various channels into the South Blanco River and the Los Patos River. Both faults El Cura and Penitentes have an elevated eastern block (Fig. 2).

These tributaries feed major rivers; the Blanco River, Agua Negra stream and Iglesia stream flow into the Jáchal River, while the Castaño and Los Patos Rivers flow into the San Juan River. Both the Blanco and Los Patos Rivers represent examples of courses that must run hundreds of kilometers in the north-south direction before overcoming obstacles that impede their passage toward the east (Fig. 2).

The western border of the Precordillera (Figs. 1 and 2), which is marked by the Uspallata - Barreal-Calingasta - Iglesia Valley represents a significant obstacle that has only been crossed by the largest collectors: the Jáchal, San Juan, and Mendoza rivers. The Jáchal River and the San Juan River are clearly antecedents. The Jáchal River crosses the Precordillera along a zone of weakness caused by a lateral ramp (Damanti 1993).

Finally, toward the east, the rivers that descend from the Frontal Cordillera and the Precordillera feed the Bermejo-Desagüadero system running parallel to the western front of the Sierras Pampeanas which, at these latitudes, constitute an insurmountable barrier for surface water. The Bermejo Desaguadero system flows for more than $1000 \mathrm{~km}$ along this barrier before turning eastward and dumping its waters into the Colorado River, which then runs to the Atlantic (Figs.1, 2 and 3).

The diversion of the rivers that descend through the eastern flank of this Andean segment is due to the rapid rise of obstacles. The rivers are diverted when there is a limited sediment contribution that is exceeded by the rate of obstacle uplift or there is a rapid uplift (Humphrey and Konrad 2000). In this case, there is no doubt that the sediment contributions were very abundant due to the intense action of gravitational and glacial-fluvial processes (Suriano and Limarino 2008, Perucca and Esper 2009, Perucca et al. 2009). Rapid uplift has been demonstrated in the western margin of the Precordillera (Cortés and Costa 1993).

A regional schematic cross-section of the Andes at $30^{\circ} 15^{\prime} \mathrm{S}$. Lat., showing the main tectonic units and its relationships, was made by the authors. The subsurface information was inferred and extrapolated from surface data, using cross-section balancing techniques, figure 4.

The eastern migration of deformation during the last 20 Ma has been recognized by various authors, such as González Bonorino (1950), Groeber (1951), Polanski (1962), and Cortés (1993), among others. In the eastern Precordillera and in the western Sierras Pampeanas, thrusting occurred between 5 and $2.5 \mathrm{Ma}$ (Siame et al. 2006).

The Bermejo Valley, the Tulum Depression, and the eastern plain of Mendoza (Fig. 1), which are situated between the Precordillera and the border of the Sierras Pampeanas, represent a current zone of high seismicity and pronounced tectonic activity. High rates of rise have been recorded for the surrounding mountains and confirmed by geodetic measurements. Rises of up to 1.2 $\mathrm{m}$ have been recorded in the mountains of Pie de Palo range (Fig. 5) since the earthquake of 1977, which had a magnitude of 7.4 (Suvires et al. 1995, Martínez et al. 2008). In addition to the linear obstacles that have been described, there are positive buried structures that have also produced river diversions, including the high of Médanos Grandes and the structural high of Mendoza Norte - Tunuyán (Criado Roque et al. 1981) (Fig. 2). These structures, along with the mountains of Pie de Palo, are probably recent obstacles associated with the ongoing deformation that is advancing towards the east. The Pie de Palo ranges are associated with a marked superficial seismic anomaly that is indicative of current activity and has been actively growing since 5-3 Ma (Siame et al. 2006). This sector currently demonstrates the phenomena that have been operating throughout this section of the Andes during the last $20 \mathrm{Ma}$, diverting and concentrating the rivers that run towards the Atlantic. Regional tectonic is the main drivers of river diversion in this region.

A geological cross profile AA' was made at $30^{\circ} 15^{\prime} \mathrm{S}$ latitude where the authors show the majority of the faults that act as obstacles in the courses of the rivers are oriented parallel to the mountain ranges, especially the slopes towards the west that have elevated eastern block faults (Fig. 5). They have regional extents of tens of kilometers.

In addition the main obstacles that have been recognized and that have also produced river diversions, including magmatic bodies, structural high and the progradation of San Juan River alluvial fan into Tulum valley.

Magmatic bodies Because the intrusive bodies of the Frontal and Principal Cordilleras are highly resistant to erosion, they have diverted rivers and have produced drainage network configurations that conform to their morphology. Circular or elliptical drainage 

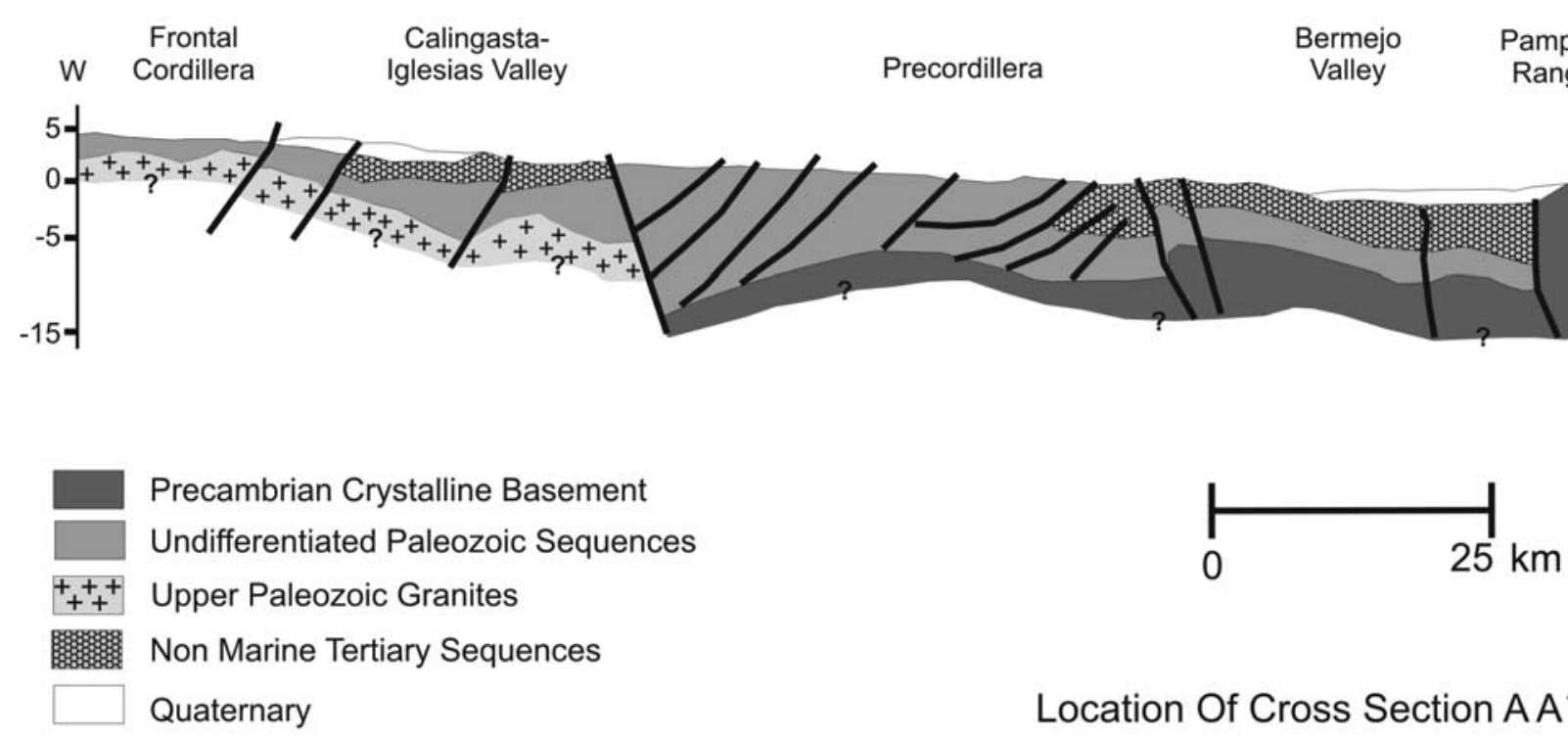

Location Of Cross Section A A'in Fig 2

Figure 4 - Regional schematic cross-section of the Andes at 30'15'S Lat., showing the main tectonic units and its relationships. The subsurface information was inferred and extrapolated from surface data, using cross-section balancing techniques.

configurations also develop in places where there are no intrusive outcrops, which may be interpreted as indicators of subsurface intrusive or subvolcanic bodies. The plutons developed during the Upper Paleozoic exert lithological controls on rivers, especially between $29^{\circ} \mathrm{S}$ and $30^{\circ} \mathrm{S}$, forming wide curves or deep canyons. The Colangüil batholith represents an example of these phenomena. (Fig. 2).

Blind faults and structural highs Outside of the Andean region, some subsurface obstacles have no apparent relation with known faults. It is probable that these obstacles have been uplifted by blind faults and that structural highs represent underground folds such as Mendoza Norte and Médanos Grandes to the south of the Pie de Palo range in San Juan (Fig. 5). The highs of Mendoza Norte are an elevated block of basement detected by seismic refraction at approximately 1500 $m$ depth (Ortiz et al. 1976). The uplift is manifested on the surface only by the diversion of the courses of the alluvial fan formed by the Mendoza and Tunuyán rivers. Between these rivers, the obstacles correspond to the Late Cenozoic alignments and structural uplift of the foothills. The Quaternary deposits that cover these extensive plains would have been accumulated by an ancient alluvial fan formed by the Mendoza, Tunuyán, and San Juan rivers, which is currently covered by dunes forming a discontinuous sandy mantle that partly exposes the ancient river channels (Fig. 2).

Progradation of the San Juan River alluvial fan The Mogna hills links the Pie de Palo range with the eastern Precordillera. The southern end of the intermediate basin was produced by the progradation of the alluvial fan formed by the San Juan River upon entering the Tulum valley (Zambrano \& Suvires 2005, 2008). The tectonic uplift of the Mogna hills continued during the Quaternary until it separated the valleys of Bermejo and Tulum. This structure loses height from west to east; its topographic difference from the valleys is reduced in the east. It is probable that the Bermejo River flowed into the San Juan River in recent times (Suvires et al. 1999) (Fig.1).

DISCUSSION Modern geographical features began to acquire their current configuration during the Miocene, after the Pehuenche phase, at approximately $22 \mathrm{Ma}$ (Salfity \& Gorustovich 1984). The subsequent Quechua and Diaguita phases (Reynolds et al. 1997, Jordan et al. 1997) and neotectonic movements increased the mountain range elevation and reactivated faults, generating new obstacles toward the east. The drainage pattern evolved through successive stages (Litvak \& Poma 2005) that accompanied the tectonic evolution 


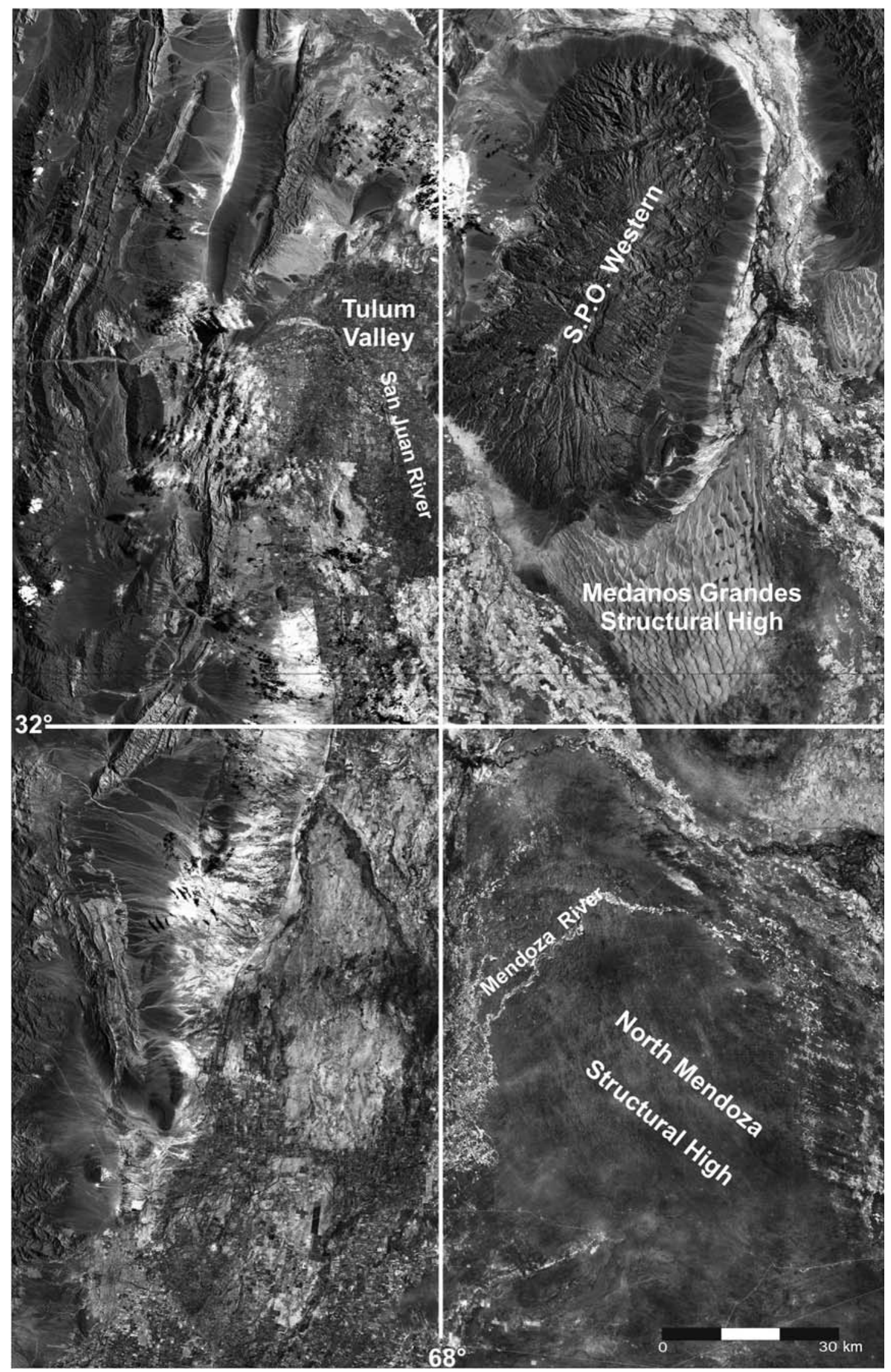

Figure 5 - Satellite image of the Bermejo valley. In the north-east corner is the Pie de Palo Range which exerts a clear control in the rivers flow. The rivers are impeded to flow to the east and flow around the structure. In the south-east corner is the buried North Mendoza High which controls the drainage approximately in the same way as the Pie de Palo Range but it is a not outcropping structure. 
of the Andes, where superimposed orogenic structures have been recognized. The uplift of the Principal Cordillera occurred between 20 and 8.6 Ma (Ramos 1996, Ramos et al. 2002), and the Frontal Cordillera had its maximum uplift at $9 \mathrm{Ma}$ (Cortés 2008). Deformation propagated towards the east, resulting in the rise of the folded strip of the Precordillera, which culminated at 2.6 Ma (in the Pliocene Epoch) and continued during the Quaternary (Ramos et al. 2002). Even more recent deformations, which are found farther east in the Bermejo valley, are associated with intensive current seismicity and changes in geodetic measurements.

The first obstacles to produce drainage concentration coincide with the steps related to the Penitentes and Cura Valley faults, which are located in a zone of high peaks in the westernmost edge of the area near the continental divide (Fig. 2). These faults form part of a larger structure that is concavely curved toward the east and discontinuously exposed. The northern segment runs NNE (El Cura fault), and the southern segment runs NNW (Penitentes fault). Farther east, younger obstacles coincide with the faults that mark the back-thrust front of the western border of the Precordillera. These obstacles control the large, north-south-oriented rivers like the Blanco River, the main tributary of the Jáchal, and the Los Patos River, a tributary of the Juan River. Notably, these structures along the edge of the Precordillera efficiently divert major drainage rivers for the Andes like the Jáchal and San Juan Rivers, which subsequently flow to the east, crossing the mountains of the Precordillera as antecedent rivers. The Mendoza and Tunuyán rivers run toward the east, curving around the obstacles imposed by the highs of Mendoza Norte and Cerrillada Pedemontana until finally being retained and diverted by the Desagüadero - Bermejo fault on the western border of the Sierras Pampeanas (Figs. 1, 2, 3 and 4) to form the headwaters of the Colorado River.

CONCLUSIONS The evolution of the drainage of the eastern Andean flank across 1,000-km section between $27^{\circ} \mathrm{S}$ and $34^{\circ} \mathrm{S}$ is a powerful indicator of the tectonic phenomena that occurred between the Early Miocene and Late Quaternary Periods. This region has previously been identified as an area of intense seismic activity and Quaternary tectonics, and the current drainage pattern analysis confirms and reinforces this conclusion. Recent tectonics have produced a set of obstructions that divert rivers, culminating in an impressive final concentration of all of the runoff from this large Andean section reaches the Atlantic by a single collector trunk, the Colorado River. Structures along the western edge of the Precordillera and the Desagüadero - Bermejo faults very effectively contain and divert the rivers that come from the west. Certain rivers must have run for hundreds of kilometers parallel to these structures before being able to follow their course toward the east. The morphostructural controls of the drainage pattern decrease in age from north to south and from west to east. Late Cenozoic structural features like the high of Médanos Grandes, Mendoza Norte, and Cerriladas Pedemontanas, correspond to structures that were produced by the most recent Quaternary surface deformation. All of these are situated in the Bermejo valley, which hosts intense seismic and neotectonic activity, as demonstrated by instrument measurements. Back-thrusts most efficiently control and divert rivers. From west to east, these structures correspond to the Penitentes system, El Cura fault, the back-thrust front of the Precordillera, and the Bermejo - Desaguadero faults (Fig. 2). The tectonic regime of the Andean Chain and in its foreland shifts significantly at $27^{\circ} \mathrm{S}$, which is reflected in drainage behavior. North of $27^{\circ} \mathrm{S}$, an endorrheic watershed is represented by La Puna, which acts as an intermediate area of surface water retention and blocks the rivers that begin in the high peaks from directly descending to the foreland. South of this section, the extreme north of the Sierras Pampenas is incorporated into the Andean Chain and does not represent an obstacle for surface runoff. To the south of $27^{\circ} \mathrm{S}$, the rivers with headwaters in the high peaks of the continental divide flow directly toward the foreland. The western edge of the Sierras Pampeanas represents a very significant obstacle in this section that concentrates all of the channels that descend through the eastern Andean flank into the Colorado River, a primary artery flowing directly toward the Atlantic. The larger structures that regulate these changes are thought to represent features inherited from Paleozoic orogenies, especially the Ocloyicas Orogeny, which have been reactivated by recent tectonics (Mon 1993).

\section{References}

Alvarado P., Beck S., Zandt G. 2007. Crustal structure of the south-central Andes Cordillera and backarcregion from regional waveform modelling. Geophys. J. Int., 170:858875. doi: 10.1111/j.1365-246X.2007.03452.x.

Cortés J.M. 1993. El frente de corrimiento de la Cordillera
Frontal en el extremo sur del valle de Uspallata, Mendoza. In: Congreso Geológico Argentino, 12, Congreso de Exploración de Hidrocarburos, 2, Actas, p. 168-178.

Cortés J. M. 2008. Escalas de control paleotectónico en la deformación andina ( $\left.33^{\circ} \mathrm{S}\right)$, Argentina. In: Congreso 
Geológico Argentino, 17, Actas, p. 17-18.

Cortés J.M. \& Costa C.H. 1993. La deformación cuaternaria pedemontana al norte de la Pampa Yalguaraz, margen occidental de la Precordillera de San Juan y Mendoza. Congreso Geológico Argentino, 12, Congreso de Exploración de Hidrocarburos, 2, Actas, p. 241- 245.

Cortés J.M., Casa A., Pasini M., Yamín M., Terrizzano C. 2006. Fajas oblicuas de deformación neotectónica en

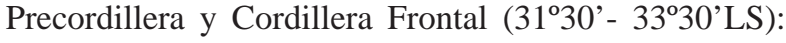
controles paleotectónicos. Revista de la Asociación Geológica Argentina, 61(4):639-646.

Costa C., Audemard F., Bezerra F., Lavenu A., Machette M., Paris G. 2006. An Overview of the main Quaternary deformation of South America. Revista Asociación Geológica Argentina, 61(4):461-479.

Criado Roque P., Mombrú C., Ramos V.A. 1981. Estructura e interpretación tectónica. In: Yrigoyen M.R. (ed.) Geología y Recursos Naturales de la provincia de San Luis. San Luis, AGA, p. 155-192.

Damanti J.F. 1993. Geomorphic and structural control on facies patterns and sediment composition in a modern foreland. In: Marzo M. \& Puigdefabregas C. (eds.) Alluvial sedimentation: International Association of Sedimentologists Special Publication. Hoboken, WileyBlackwell, p. 221-233.

Furque G. \& Cuerda A.F. 1979. Precordillera de La Rioja, San Juan y Mendoza. In: Simposio de Geología Regional Argentina, 2, Actas, p. 455-522.

González Bonorino, F. 1950. Geological cross-section of the Cordillera de los Andes about parallel $33^{\circ}$ lat. Geological Society of America Bulletin, 61(1):17-25.

Groeber P. 1951. La alta Cordillera entre las latitudes $34^{\circ}$ y 29³0'. Revista del Museo Argentino de Ciencias Naturales, Ciencias Geológicas, 1(5):1-352.

Gupta S. 1997. Himalayan drainage patterns and the origin of fluvial megafans in the Ganges foreland basin. Geology, 25(1):11-14.

Humphrey N.F. \& Konrad S.K. 2000. River incision or diversion in response to bedrock uplift. Geology, 28(1):43-46.

Jordan T., Reynolds J.H., Erikson J.P. 1997. Variability in age of initial shortening and uplift in the Central Andes, 16-3330’S. In: Ruddiman W. (ed.) Tectonic Uplift and Climate Change. New York, Plenum Press, p. 41-61.

Lavenu A. 2006. Neotectónica de los Andes entre $1^{\circ} \mathrm{N}$ y $47^{\circ}$ $\mathrm{S}$ (Ecuador, Bolivia y Chile): Una revisión. Revista de la Asociación Geológica Argentina, 61(4):504-524.

Litvak V.D. \& Poma S. 2005. Estratigrafía y facies volcánicas y volcaniclásticas de la Formación Valle del Cura: magmatismo paleógeno en la Cordillera Frontal de San Juan. Revista de la Asociación Geológica Argentina, 60(2):402-416.

Martinez M.P., Perucca L.P., Giménez M.E. \& Ruiz F. 2008. Manifestaciones geomorfológicas y geofísicas de una estructura geológica profunda al sur de la sierra de Pie de Palo, Sierras Pampeanas. Revista de la Asociación Geológica Argentina, 63(2):264-271.

Minetti J. 1984. Régimen de frecuencia de la precipitación sólida en la República Argentina y en la Antártida. Revista de Geofísica, 21:75-113.
Minetti J. 1986. El régimen de precipitaciones de la provincia de San Juan y su entorno. San Juan, Centro de Investigaciones Regionales, Informe Técnico 8, 47 p.

Mon R. 1993. Influencia de la Orogénesis Oclóyica en la segmentación andina en el norte argentino. In: Congreso Geológico Argentino, 12, Actas, p. 65-71.

Mon R. 2005. Control tectónico de la red de drenaje de los Andes del norte argentino. Revista de la Asociación Geológica Argentina, 60(3):461-466.

Ortiz A., Zambrano J.J., Perucca J.C. 1976. Evaluación geomorfológica de los ríos Mendoza y Tunuyán. San Juan, Instituto de Investigaciones Mineras, Informe Técnico, 38 p.

Perucca L., Mehl E.A., Zarate M.A. 2009. Neotectónica y sismicidad en el sector norte de la depresión de Tunuyán, provincia de Mendoza. Revista de la Asociación Geológica Argentina, 64(2):263-274.

Perucca L. \& Esper Y. 2009. El deslizamiento de rocas y detrito sobre el río Santa Cruz y el aluvión resultante por el colapso del dique natural, Andes Centrales de San Juan. Revista de la Asociación Geológica Argentina, 65(3):571-585.

Polanski J. 1962. Descripción geológica de la hoja 25 a Volcan San José (Provincia de Mendoza). Buenos Aires, Dirección Nacional de Geología y Minería, Boletín 98, $94 \mathrm{p}$.

Potter P.E. 1978. Significance and origin of big rivers. Journal of Geology, 86:13-33.

Prieto M.R. \& Herrera R. 2002. Evidencias históricas sobre algunos aspectos de variabilidad climática en Argentina y Bolivia durante los últimos cuatro siglos. In: Trombotto D. \& Villalba R. (eds.) IANIGLA, 30 años de investigación básica aplicada en ciencias ambientales. Mendoza, IANIGLA-CRICyT, p. 133-137.

Ramos V.A. 1996. Evolución tectónica de la alta cordillera de San Juan y Mendoza. In: Ramos V.A. (ed.) Geología de la región del Aconcagua, provincias de San Juan y Mendoza. Buenos Aires, Subsecretaría de Minería de la Nación - Dirección Nacional del Servicio Geológico, p. 447-460.

Ramos V.A., Cristallini E.O., Perez D. 2002. The Pampean flat-slab of the Central Andes. Journal South American Earth Sciences, 15:59-78.

Reynolds J., Ramos V.A., Jordan T.E., Hernández R.M. 1997. Diachronism of regional Neogene stratigraphy in the Andean foreland, NW Argentina: the Calchaquense and Aracaunense terminology. In: Geological Society of America - Annual Meeting. Salt Lake City, Geological Society of America, Abstracts, p. 228.

Salfity J. \& Gorustovich S.A. 1984. Paleogeografía de la cuenca del Grupo Paganzo. Paleozoico superior. Revista de la Asociación Geológica Argentina, 38:437-453.

Siame L.L., Bellier O., Sebrier M. 2006. Active tectonics in the Argentine Precordillera and western Sierras Pampeanas. Revista de la Asociación Geológica Argentina, 61(4):604-619.

Snaider P.P. 2002. Las precipitaciones nivales en la República Argentina. In: Universidad Católica de Santa Fe, Facultad de Ingeniería, Geoecología y Medio Ambiente, Jornadas Nacionales de Geografía Física, 3, Resúmenes, 
4 p. Disponível em: http://www.inti.gov.ar/cirsoc/pdf/ acciones_nieve_hielo/h-039.pdf.

Suriano J. \& Limarino O.C. 2008. Sedimentación pedemontana en las nacientes del río Jáchal y Pampa de Gualilán Las precipitaciones nivales en la República Argentina. Universidad Nacional del Nordeste, Precordillera de San Juan. Revista de la Asociación Geológica Argentina, 65(3):516-532.

Suvires G., Sisterna J., Quiroga M. \& Robles A. 1995. Generación de relieve cuaternario por efectos pre, co y pos-sísmicos en la intersección del paralelo de 31³0’ de latitud sur y el meridiano de 6800' de longitud oeste de Greenwich. Argentina. In: Congreso Latinoamericano de Geología, 9, Actas, p. 5-15.

Suvires G., Zambrano J., Pereyra B. \& Oviedo M. 1999. Posible antiguo cauce del río Jáchal en la depresión intermontana del valle del Tulum, San Juan. In: Congreso de Geomorfología y Cuaternario, 1, Actas, p. 63-69.

Suvires G.M. 2008. Geomorfología. In: Carretero E.M. (ed.) Diversidad biológica y Cultural de los Altos Andes Centrales de Argentina. Línea de base de la Reserva de Biosfera San Guillermo-San Juan. San Juan, Fundación
Universidad Nacional de San Juan, p. 91-100.

Turner J.C.M. 1979. Puna. In: Simposio de Geología Regional Argentina, 2, Actas, p. 91-116.

Yrigoyen M.R. 1979. Cordillera Principal. In: Simposio de Geología Regional Argentina, 2, Actas, p. 651-694.

Zambrano J.J. \& Suvires G. 2005. Aporte a la Geología del Alto de Mogna, al norte de la depresión del Tulum, provincia de San Juan. Revista Asociación Geológica Argentina, 60(2):425 -427.

Zambrano J.J. 2008. Geología. In: Carretero E.M. (ed.) Diversidad biológica y Cultural de los Altos Andes Centrales de Argentina. Línea de base de la Reserva de Biosfera San Guillermo-San Juan. San Juan, Fundación Universidad Nacional de San Juan, p. 51-60.

Zambrano J.J. \& Suvires G. 2008. Actualización en el límite entre sierras Pampeanas Occidentales y Precordillera Oriental, en la Provincia de San Juan. Revista de la Asociación Geológica Argentina. 63(1):110- 116.

Manuscrito ID 22836

Submetido em 30 de agosto de 2011 Aceito em 07 de fevereiro de 2012 